\title{
Erratum to: An application of AVO derived attributes to analyze seismic anomalies of gas hydrate bearing sediments in Makran offshore, Pakistan
}

Muhammad Irfan Ehsan ${ }^{1}$ Nisar Ahmed ${ }^{2}$ Zia Ud Din ${ }^{2}$. Perveiz Khalid $^{2} \cdot$ Liu Xue Wei ${ }^{1}$

Published online: 11 July 2016

(C) Akadémiai Kiadó 2016

\section{Erratum to: Acta Geod Geophys DOI 10.1007/s40328-015-0146-0}

Author name was incorrectly published and should be read as Muhammad Irfan Ehsan.

The online version of the original article can be found under doi:10.1007/s40328-015-0146-0.

Muhammad Irfan Ehsan irfan_opq@yahoo.com

1 School of Geophysics and Information Technology, China University of Geosciences, Beijing 100083, China

2 Institute of Geology, University of the Punjab, Lahore 54590, Pakistan 